\title{
2006-2065: DESIGN BOOT CAMP: GETTING IN SHAPE FOR A CAPSTONE
}

EXPERIENCE

\section{Renee Rogge, Rose-Hulman Institute of Technology}

RENEE D. ROGGE is an Assistant Professor of Applied Biology and Biomedical Engineering. Her teaching interests include orthopaedic and sports biomechanics, biomaterials, capstone design, and introductory level mechanics courses.

\section{Glen Livesay, Rose-Hulman Institute of Technology}

GLEN A. LIVESAY is an Associate Professor of Applied Biology and Biomedical Engineering. He teaches undergraduate and graduate courses on biomechanics, capstone design, experimental design and data analysis, and experimental biomechanical testing of soft tissues. 


\title{
Design Boot Camp: Getting in Shape for a Capstone Experience
}

\begin{abstract}
Boot camp is a training ground for military recruits. The rigors of this experience prepare soldiers for futures in the military. During boot camp, recruits with varied backgrounds are immersed in an environment where they get a "crash course" in strategies that will lead them to success. Similar to a military career, a capstone design experience can be quite stressful to students. However, most engineering programs lack a solid training ground, or boot camp, to indoctrinate students to the world of design. It should come as no surprise that students tend to dread, or even fear, senior design courses. Their fear of the unknown is compounded by the things that they do know, e.g. they know they must (1) select (and solve) an open-ended design problem, (2) work productively as a team, (3) document the design process (which they do not understand), and (4) present (and defend) the results of their efforts to a large audience. Even the most daring of students may be intimidated by this!

Our "Design Boot Camp" is called Principles of Biomedical Design. In this required two credit course, junior biomedical engineering majors are introduced to engineering design methodology. This paper will discuss the layout of the course, the perceived benefits for both students and instructors, and the lessons learned during the first iteration of the course.
\end{abstract}

\section{Introduction}

Many engineering programs have freshman engineering courses designed to introduce students to the design process early in their careers. Such courses typically focus on communication skills, team work, self-evaluation and reflection, systematic approaches to problem solving, and generating and considering alternative solutions. ${ }^{1}$ These are critical engineering skills to master and provide freshman with a glimpse into their futures as engineers. In addition, successful experiences in such courses have been correlated with higher retentions rates. ${ }^{2}$ However, an intense biomedical engineering design experience at the freshman level is difficult to achieve since most "real world" design experiences require advanced analytical skills and body of knowledge that is not readily attainable at the freshman level.

An alternative approach to the freshman-level introduction to design course is an upper-level course taken as a precursor to the senior design capstone course. At this institution, this course is called Principles of Biomedical Design. At the junior level, students already have extensive experience working in teams, communicating in both written and oral forms, and solving problems. An upper-level course can take advantage of student maturity in this skill set to enhance the performance and understanding of the design process.

\section{Course Layout}

In the Principles of Biomedical Design course, junior biomedical engineering majors are introduced to the engineering design methodology as utilized in biomedical engineering. Students apply engineering design principles through completion of a team design project with 
realistic constraints. The course serves as the entry point for the four-quarter sequence in which students undertake and complete their capstone design project.

Principles of Biomedical Design is a two-credit, required course for all biomedical engineering students in the spring quarter of their junior year. The course meets twice a week, with one 50minute lecture session and one 160-minute laboratory session. A unique feature of this course is its overlap with the final quarter of the senior design sequence. Half of the laboratory exercises in this course incorporated the seniors as mentors to help guide the less experienced juniors through what the seniors considered "familiar territory".

The course objectives for Principles of Biomedical design include the following:

1. Assessment of client needs to establish problem-specific constraints

2. Identification of relevant constraints (e.g. regulatory, manufacturing, economic, environmental, societal, etc.)

3. Formulation of problem statements that incorporate client input and relevant constraints.

4. Generation of multiple, creative solutions for a problem and development of criteria by which to rank the merit of feasible solutions.

5. Critical reviewing the performance of a solution to evaluate the achievement of identified needs and suggesting relevant improvements or necessary revisions.

To meet the course objectives and prepare the students for the capstone senior project, many topics were discussed in lecture and reinforced through laboratory experiences. The lecture and lab topics included:

- Client interactions and developing problem statements

- Identifying and evaluating constraints

- Generating multiple design solutions

- Using feasibility and merit criteria to make decisions

- Developing a prototype

- Developing, implementing, and evaluating test plans

- Multidisciplinary design and regulatory issues

- Reverse Engineering

- Project Documentation

- Technical communication

During this 10-week crash course, or "boot camp", in biomedical design, the students complete an entire mini-design project. The students identify client needs, formulate problems statements, identify design constraints, generate and evaluate multiple feasible solutions to a design challenge, and document the entire design process. Although the experience is intense and comes with a high workload, the students are aware of the importance of the process and willing to invest their efforts.

\section{Lessons Learned \& Future Plans}

Though this course has only been offered once, many valuable lessons have been learned and will be incorporated into the future offerings of this course. The "mini" project must be carefully 
selected in order to capture the imagination and attention of the students in the course. It must be sufficiently challenging to push the boundaries of the students' abilities, but must also be "doable" in a 10-week course. The students are willing to put the time and energy into a design project, but they also want the benefits of successfully tackling a real-world problem with real applications.

The project should also be introduced in the early stages of the course. In the first offering, the project was not introduced until midway through the quarter. This was done so that the student's could focus on the design content and associated labs early in the quarter. In the future, the project will be presented in the very beginning of the course and the project can be used as an example to reinforce the concepts discussed in lecture and lab.

Some formal assessment of the impact of this approach to design is important and steps are being taken to accomplish this task. One of the metrics in progress is tracking the evolution of a concept map for design over time to gauge the development of the student's perception of the design process.

\section{Conclusions}

There are many benefits to a "boot camp" approach to design. After completing the course, the students know what to expect, in general, from the senior design sequence and the fear of the unknown is removed (or at least diminished). The students also have the information they need to make an informed decision about projects for senior design, i.e. they have a feeling for the amount of work required for a project. Another benefit to the students is their ability to practice the complete design process in a safe environment where a "less than exceptional" design solution is not devastating to the student. Since all student teams are working on solutions to a common problem, the demonstration of multiple feasible solutions to an open-ended problem is encouraging to many students. A benefit to the instructors in the senior design sequence is the ability of the students to "hit the ground running" with their projects in the subsequent quarter.

\section{Bibliography}

1. Sheppard, S., and R. Jenison. 1997. Examples of Freshman Design Education. International Journal of Engineering Education. 4: 248-261.

2. Paul King. 2002. Freshman Biomedical Engineering Design Projects: What Can Be Done? Proceedings, 2002 Frontiers in Education Conference: King, FIE 2005. 